\title{
ANALISIS STRATEGI BELAJAR DENGAN METODE BIMBEL ONLINE TERHADAP KEMAMPUAN PEMAHAMAN KOSA KATA BAHASA INGGRIS DAN PRONUNCIATION (PENGUCAPAN/PELAFALAN) BERBAHASA REMAJA SAAT INI
}

\author{
Ana Ramadhayanti \\ Universitas BSI \\ Antapani, Jalan Sekolah Internasional No.1-6, Cicaheum, \\ Kiaracondong, Kota Bandung, Jawa Barat \\ Email: ana.rdx@bsi.ac.id
}

\begin{abstract}
Abstrak
Penggunaan istilah asing tidak hanya dalam bahasa Indonesia namun juga dalam bahasa Inggris. Saat ini telah banyak berbagai akses yang dapat digunakan untuk melakukan pembelajaran.Melalui handphone smarphone dapat dijadikan sebagai akses dalam pembelajaran.Hingga saat ini muncullah teknologi berbasis pendidikan yakni beberapa situs resmi berbasis pendidikan yang ditayangkan seacara online.Pembelajaran berbasis online dalam bentuk video ini menyediakan berbagai mata pelajaran, bahkan terdapat juga materi pembelajaran untuk persiapan masuk perguruan tinggi negeri.Dari sekian mata pelajaran satu diantaranya Bahasa Inggris, beberapa siswa memanfaatkan strategi belajar dengan metode berbasis online ini.Namun untuk mengetahui kemampuan pemahaman dan pengucapan/pelafalan perlu diteliti lebih jauh lagi. Karena metode pembelajaran berbasis online ini tidak tayangkan secara live, atau dalam arti kata hanya sebuah rekaman video, maka umpan balik dari siswa jika ingin menanyakan mengenai materi yang disaksikan di video tersebut menjadi suatu kendala tertentu. Dengan berbagai uraian diatas maka penulis tertarik ingin meneliti fenomena tersebut berdasarkan metode penelitian survei dengan pengumpulan data melalui menyebarkan quesioner dengan analisis penelitian kuantitatif. Berdasarkan kajian penelitian yang telah penulis lakukan menunjukkan kemampuan pemahaman saling berpengaruh dengan hasil penelitian yang signifikan dan positif terhadap Strategi Belajar Dengan Metode Bimbel Online. Sementara itu untuk Pronunciation (Pengucapan/pelafalan) juga saling berpengaruh dengan hasil penelitian yang signifikan dan positif terhadap Strategi Belajar Dengan Metode Bimbel Online.
\end{abstract}

Kata Kunci :Pronunciation, Bimbel Online, Bahasa Inggris.

\begin{abstract}
The use of foreign terms is not only in Indonesian but also in English. Currently there are a lot of access that can be used for learning. Through mobile phone smarphone can be used as access to learning. Until now, education-based technology has emerged as some of the official educational-based sites aired online. This online video-based learning provides a variety of subjects ranging from elementary education to high school, where there are also learning materials for state university entrance preparations. Of all the subjects one of them is English, some students take advantage of this learningbased learning strategy. But to know the ability of understanding and pronunciation / pronunciation need to be further examined. Since this online-based learning method does not live live, or in the sense that the word is just a video recording, the feedback from the student if it asks about the material witnessed in the video becomes a constraint. With the various uraiaan above, the writer is interested to examine this phenomenon by using simple random sampling research method, by collecting data by distributing quesioner with quantitative research analysis. Based on the research conducted by the author, it shows that the Ability of Understanding interacts with the result of a significant and positive study on the Learning Strategy With Online Bimbel Method. Meanwhile for Pronunciation (Pronunciation) also influence each other with a significant and positive research result on Learning Strategy With Online Bimbel Method.
\end{abstract}

Keywords: Pronunciation, Online Bimbel, English (penulisan kata kunci nonkapital)

\section{PENDAHULUAN}

Seiring dengan perkembangan komunikasi yang selalu berubah dari masa kemasa, maka setiap kata maupun tutur bahasa yang diucapkan sebagian atau banyak orang selalu melakukan perkembangan. Hal ini terlihat dari berbagai ucapan yang dituturkan oleh sebagian orang terutama anak muda maupun remaja yang menggunakan bahasa kekinian dengan istilah asing. Berbagai akses dapat dengan mudah diperoleh untuk dapat mempelajari bahasa internasional ini. 
Seolah telah menjadi bahasa resmi sehari-hari istilah asing telah banyak dijumpai baik ditempat umum maupun dalam petunjuk penggunaan suatu barang maupun produk makanan. Berbagai cara dilakukan untuk menarik minat seseorang dalam bahasa Inggris. Seperti salahnya muncul akses situs resmi yang khusus membahas mengenai materi-materi sekolah baik dari tingkat (SD), (SMP), (SMA), hingga materi uji masuk perguruan tinggi negeri. Dalam metode bimbel online ini pembelajaran yang ditayangkan dalam bentuk video. Aplikasi pembelajaran ini pada dasarnya dapat diakses melalui Handphone Smartphone berbasis Android.

Berdasarkan hasil penelitian yang dilakukan oleh Ericson sampai tahun 2011 terdapat kurang lebih 7\% remaja berumur 16-19 tahun yang menyaksikan video menggunakan Youtobe. Pada umumnya mereka menguras waktu di handphone kurang lebih tiga jam sehari. Angka tersebut mengalami kenaikan sekitar $20 \%$ setelah empat tahun yang akan datang Ericson dalam (Gideon, 2018).

Terdapat berbagai mata pelajaran yang ada aplikasi berbasis online ini seperti salah satunya bahasa inggris. Pelajaran asing ini memang sampai kapanpun tetap diperlukan, hingga tidak heran jika terdapat berbagai lembaga kursus atau bimbel sebagai penyedia jasa koseling atau privat. Namun seiring dengan adanya bimbel berbasis online membuat menarik beberapa orang khususnya siswa/i yang memanfaatkan aplikasi bimbel online ini sebagai bantuan dalam belajar. Bimbel online ini merupakan sebuah situs aplikasi yang menayangkan video mengenai materi pelajaran. Bimbel online ini secara mudah dapat diinstal melalui aplikasi Android yang ada di Smartphone. Hingga saat ini telah banyak iklan yang menyajikan bimbel online, baik di media televisi maupun toko buku.

Dalam suatu iklan terdapat unsur slogan serta klaim. Pada umumnya slogan adalah wacana yang gampang diingat, seperti perkataan yang singkat serta suatu icon yang unik atau berciri khas Ihza dalam (Mariyanto, 2017)

Secara mudah dan praktis siswa/i dapat belajar dimanapun dan kapanpun semaunya. Namun dibalik beberapa keunggulan dari metode bimbel online ini ada satu hal yang kurang dimiliki oleh bimbel online ini. Berbeda dengan bimbel online secara tatap muka atau pada umumnya, dalam bimbel online siswa/i tidak terdapat akses tanya jawab. Setelah diuraikan secara mendalam dari berbagai pemasalahan diatas, peneliti ingin mengkaji lebih jauh permasalahan tersebut dalam sebuah penelitian mengenai Analisis Strategi Belajar Dengan Metode Bimbel Online Terhadap Kemampuan Pemahaman Kosa Kata Bahasa Inggris dan Pronunciation

(Pengucapan/pelafalan).

Penelitian yang dilakukan oleh (M.Zaim, 2013)menerangkan bahwa pelajaran bahasa inggris seharusnya lebih ditekankan penilaian bersifat asli seperti praktek mendengarkan, bicara, membaca dan menulis.

\section{KAJIAN TEORI}

\section{Gaya Bahasa}

Setiap kali seseorang memakai bahasa, ia selalu melakukan pemilihan bentuk bahasa (bunyi, 
kata, gabungan kata, kalimat, dan lain-lain).

Pelafalan dalam suatu kata memegang peran yang cukup penting sebab menyangkut dengan kemajuan atau pertumbuhan kosakata menurut Tarigan dalam (Sofiyanti, 2014).

Hasil penelitian (Jaya, 2017) menunjukkan aksentualisasi dan bimbingan yang dilakukan secara rutin dapat menaikkan sistem pengucapan atau logat dalam implementasi berbicara serta segelintir yang tidak dapat mengucapkan dengan benar.

Sekumpulan bentuk bahasa yang sengaja dipilih pengarah untuk mengungkapkan maksud akan menyusun ciri-ciri tertentu. Ciri-ciri ini bisa saja berbeda dengan ciri-ciri yang terjadi dari pemilihan bentukbentuk bahasa yang lain(Warsiman, 2016).

Gaya bahasa dalam retrorika umumnya diketahui dengan sebutan style. Pada dasarnya style berasal dari bahasa latin Stilus yang memiliki arti alat menulis di lempengan lilin. Namun pada waktu penekanan lebih difokuskan mengenai keahlian untuk menulis indah, setelah itu style berubah makna menjadi kemampuan serta keahlian dalam menulis atau menggunakan kata-kata secara indah(Keraf, 2007)

Gaya bahasa merupakan suatu perasaan yang dilahirkan dari suatu perkataan penulis yang dapat menyentuh perasaan pembaca Muljana dalam Waridah (2008:322).

\section{Kosa Kata}

Kosa kata merupakan semua kata yang diucapkan oleh seseorang akan terdapat dalam memori ingatan langsung menimbulkan rangsangan baik didengar dan dibaca(Keraf, 2007).
"Vocabulary as words which are related one to another so the meaning depends on the context" (Cook, 2016). Artinya, kosakata adalah masing-masing kata memiliki keterkaitan antara kata yang satu dan yang lainnya. Arti terkait dari konteks kalimatnya.

Sementara itu Hornby menjelaskan dalam Oxford Advanced Learner's Dictionary mengemukakan;

Vocabulary basically has three meanings, the first number of words combined according to the right rules to form a language; Both words are known and used by someone as a profession and others; The three books contain lists of words, usually with understanding and meaning(Hornby, 2003).

Artinya, kosakata pada dasarnya memiliki tiga makna, pertama jumlah kata yang dikombinasikan sesuai peraturan yang tepat untuk membentuk suatu bahasa; Kedua kata yang diketahui dan digunakan oleh seseorang serta profesi dan yang lainnya ; Ketiga buku yang berisi daftar kata, biasanya dengan pengertian dan artinya.

L.B Curzon dalam (Permadi, 2014) secara etimologis, dalam kamus Inggris Indonesia, kata penguasaan berasal dari kata domination yang merupakan kata benda. Tetapi dalam kamus hukum hanya dikenal istilah dominium yang identik dengan 'owenershio' (kepemilikan), yaitu 'in its original sense, single and indivisible, absolut and exclusive'.

Vocabulary merupakan gabungan kosakata yang dapat dipakai sebagai alat komunikasi untuk seluruh orang Bamhart dalam (Herlina, 2015)

Disamping pengertian penguasaan, terdapat pula istilah 
menguasai. Pada dasarnya penguasaan maupun menguasai digunakan dalam makna jasmani dan makna yuridis, dan memiliki aspek hukum perdata dan publik Boedi Harsono dalam (Permadi, 2014)

\section{Kemampuan Pemahaman}

Kemampuan yang dimiliki seseorang menjadi dasar utama dalam diri seseorang dalam meraih suatu kesuksesan. Namun yang menjadi suatu permasalahan dalam diri tenaga pendidik adalah selalu keliru memaknai arti kemampuan dalam konteks yang tidak luas (Chatib, 2011). Berikut ada tiga kemampuan yaang ada dalam diri seseorang Benjamin S. Bloom dalam (Chatib, 2011):

- Keterampilan yang terdapat dalam diri seseorang disebut sebagai kemampuan kognitif;

- Keahlian yang menghasilkan suatu karya dapat dimaknai sebagai kemampuan psikomotorik;

- Daya yang dimiliki seseorang dalam bersikap merupakan kemampuan afektif.

Bloom, Lebih lanjut lagi (Sumarmo, 2004) menjelaskan mengenai konsep Skemp membagi pemahaman menjadi dua seperti pemahaman instrumental dan pemahaman relasional.

\section{Pengertian Belajar}

Tahap dalam belajar dalam diri seseorang akan mengalami suatu metamorfosa dilihatkan dalam bentuk kenaikan mutu dan kapasitas perilaku yang ada dalam diri seseorang sebagaimana meningkatnya kepandaian, kepintaran, tingkahlaku, pengertian, akal budi serta daya lainnya (Hakim, 2005)
Berlandaskan mengenai makna belajar dapat diringkas bahwa seseorang dapat dikatakan mengalami kenaikan mutu atau taraf kemampuan yang terdapat dalam diri, maka dapat disebut orang tersebut telah mengalami suatu prosedur dalam belajar dan sebaliknya jika orang tersebut tidak mengalami pengembangan dalam dirinya maka orang tersebut mengalami kekalahan dalam sistem belajar.

Hasil penelitian (Prasetya et al, 2013)menyarankan bahwa Belajar efektif pada dasarnya merupakan pola belajar yang merubah kebiasaan belajar yang kurang baik dan dapat membantu siswa yang rentan tinggal kelas.

\section{Bimbingan Belajar}

Panduan dalam belajar merupakan suatu tahap pemberian dukungan kepada perseorangan dengan tujuan memperoleh ilmu pengetahuan serta kemampuan pribadi yang diperlukan untuk beradaptasi secara bagus dan maksimal di manapun beradaMiller dalam Willis dalam(Susanto, 2018).

Biasa kursus belajar memiliki maksud berhasil dalam pembiasaan secara akademisi dengan maksimal berdasarkan kekuatan yang dalam diri murid Syamsuddin dalam (Susanto, 2018), seperti mana yang ada di standar yang ditetapkan Depdiknas dalam (Susanto, 2018) seperti berikut ini:

Merancangkan aktivitas dalam belajar serta profesi dimasa depan
a. Menumbuhkan seluruh kemampuan dan keterampilan dalam diri secara maksimal
b. Beradaptasi dengan situasi tempat bekerja
c. Menangani gangguan dan 
kesukaran yang ditemui ketika belajar, adaptasi dengan tempat pembelajaran, publik, atau situasi tempat pekerjaan.

Suherman dalam (Susanto, 2018) secara umum maupun khusus tujuan dalam bimbingan belajar atau privat dimaksudkan agar individu dapat:

a. Dapat mengukur kemampuan yang dimiliki diri sendiri secara jasmanidan kejiwaan.

b. Memahami keadaan, ketentuan dan situasi yang naik turun baik disaat gembira ataupun tidak secara pasti berdasarkan aturan perseorangan, kemasyarakatan serta sesuai anjuran kepercayaan dalam diri.

c. Mampu dalam menyusun aktivitas belajar, agenda kerja, serta aktivitas selanjutnya.

d. Meningkatkan potensi dalam diri dan menggunakan kepiawaian dengan baik

e. Dapat beradaptasi dengan ketentuan kondisi edukasi, umum, karier ataupun kepercayaan

f. Menanggulangi permasalahan dan kesukaran dalam proses belajar baik di tempat dunia pendidikan, publik, termasuk melakukan penghambatan kepada sang pencipta.

Brown (dalam Sumarwiyah, 2009:2), menyatakan bahwa bentuk layanan bimbingan belajar dengan indikator: pengaturan waktu belajar, cara mempelajari materi belajar, motivasi belajar, pengaturan waktu belajar dengan kegiatan lain, upaya mencari informasi yang menunjang, persiapan menghadapi tes/ujian.

\section{Media Pembelajaran}

Media merupakan jembatan yang dapat digunakan sebagai jembatan dalam menyebarkan suatu pesan, catatan, laporan, warta dan sejenisnya Sadiman dalam (Sofiyanti, 2014).

Media Pembelajaran merupakan semua perangkat yang digunakan dengan maksud untuk pendidikan baik dalam bentuk media massa maupun cetak sebagai contoh majalah, koran, radio, televisi, buku dan sejenisnya. Semua alat tersebut jika dipakai dan diprogram dalam ranah pendidikan maka media tersebut termasuk dalam media pembelajaran Rossi dan Breidle dalam (Sofiyanti, 2014).

\section{Bimbingan Belajar Online}

Bimbingan belajar atau les privat selain bisa dilakukan secara langsung juga bisa dilakukan secara online (Enterprise, 2010). Bimbingan belajar secara online dirancang untuk memungkinkan proses pembelajaran jarak jauh melalui internet tanpa harus bertatap muka dengan pengajarnya. Bimbingan belajar online dapat memberikan alternatif pilihan bagi siswa yang memiliki akses jaringan internet untuk memperoleh layanan bantuan belajar yang efektif, efisien, dan interaktif secara optimal.

Lebih lanjut (Enterprise, 2010) menerangkan bahwa selain untuk mempersiapkan diri dalam menghadapi ujian, para siswa bisa mengikuti bimbingan online bimbingan belajar online ini hanya sekedar untuk belajar lebih dalam tentang bidang studi tertentu di luar apa yang sudah diajarkan guru mereka. Komunikasi antara para murid dengan tutor (guru) juga dilakukan secara online melalui video, audio, ataupun e-mail. Karena banyaknya para pelajar yang sudah bisa mengakses internet, prospek bisnis online tutoring (les privat) ini akan sangat menjanjikan. 


\section{Pronunciation}

(Pengucapan/pelafalan)

Kejelasan

pengucapan

merupakan bagian yang sangat penting dalam berkomunikasi, seperti salah satunya dalam berbicara menggunakan bahasa inggris.

Pronunciationatau pengucapan kata-kata dalam kalimat yang benar akan sangat menentukan apakah kalimat yang Anda ucapkan bisa dimengerti oleh orang lain atau tidak. Untuk mengucapkan Pronunciation dengan benar, Anda harus banyak mendengar ucapan yang benar dari orang lain yang menguasai bahasa inggris (Hakim, 2008).

Dalam proses belajar dan mengajar bahasa Inggris, aspek yang sering diabaikan adalah pelafalan (pronunciation). Hal ini dapat dilihat dengan kurangnya pelajar Indonesia yang mengenal lambang fonetik dan mengerti peranan tekanan suara (stress) dalam pengucapan(Elsjelyn, Evelyn, 2014).

Di samping itu Pronunciation setiap orang sangat dipengaruhi oleh latar belakang yang menyangkut lingkungan asal (Hakim, 2008).

Pronounciation dalam pengkajian suatu bahasa Pronounciation menjadi bagian yang penting dalam belajar sebagaimana diketahui bahwa usia mempengaruhi tuturkata beserta aksennya. Ketika belajar pronounciation akan mengaitkan peran motorik Asher dan Garcia dalam (Gusrayani, 2014) .
Kerangka Berpikir

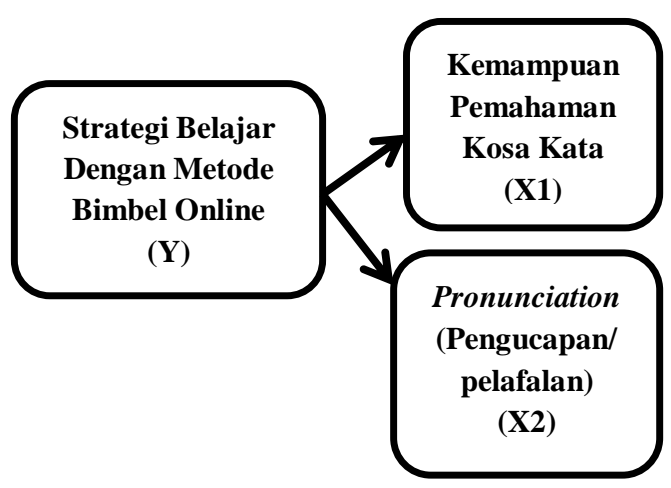

Gambar 1. Kerangka Berpikir

\section{METODE PENELITIAN}

Dalam metode penelitian ini penulis menggunakan jenis sampel acak sederhana.

Hasil penelitian
2017) (Aliwanto, penelitian Survei merupakan bentuk penelitian dimana peneliti datang atau terjun langsung ke lokasi penelitian.

Sampel acak secara sederhana merupakan setiap perwakilan yang mewakili memiliki peluang yang sama untuk diambil untuk dijadikan sebagai yang mewakili (Budiarto, 2004).

Sementara itu untuk jika dilihat dari pendekatan penelitian menggunakan penelitian kuantitatif deskriptif.

Format penelitian kuantitatif deskriptif suatu penelitian yang merangkum beragam keadaan, konteks, maupun beragam variabel yang ada di publik serta selalu objek penelitian terhadap apa yang terjadi. Setelah itu memberikan deskripsi keadaan, suasana kondisi, maupun variabel(Bungin, 2017). 
Diagram Alir Penelitian

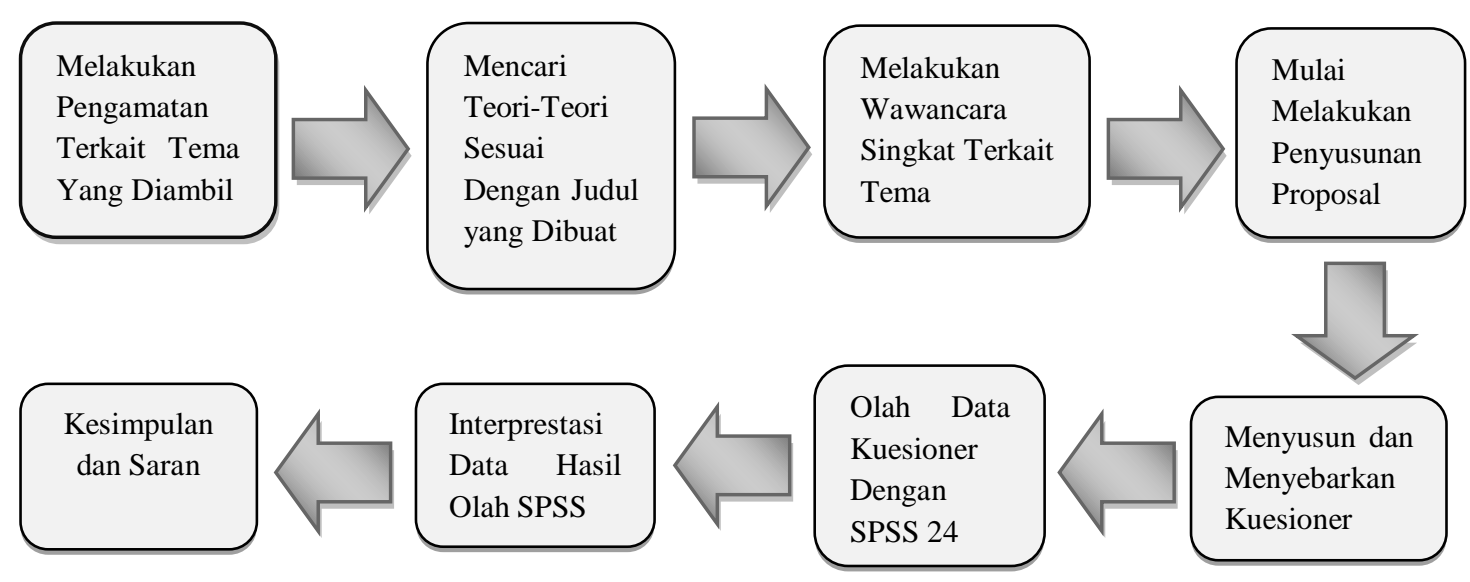

Gambar 2. Diagram Alir

Berdasarkan dari gambar 2.2 diatas maka dapat dijelaskan bahwa penelitian dimulai dari pengamatan yang menyangkut dengan tema yang diambil. Pengamatan ini bisa dilakukan dengan objek/subjek yang diteliti. Setelah itu dari hasil pengamatan lalu peneliti mencari teori-teori yang relevan terhadap penelitian tersebut. Setelah itu lalu peneliti mulai melakukan penyusunan proposal dan dilajutkan dengan pembagian kuesioner serta olah data dengan menggunakan SPSS 24 untuk mendapatkan kesimpulan dan saran dari hasil penelitian. Seperti yang telah dijelaskan dalam undang-undang menteri kesehatan Republik Indonesia No. 25 tahun 2014 yang menerangkan bahwa kategori remaja memiliki batas usia antara 10 sampai dengan 18 tahun. Sementara itu informasi yang didapatkan dari Badan Pusat Staistik menerangkan jumlah penduduk tahun 2017 berdasarkan umur 15-19 dan jenis kelamin berjumlah 26.892 .

$$
n=\frac{N}{1+N e^{2}}
$$

Penentuan besaran sampel dengan rumus slovin

Ket:

$\mathrm{n}$ = Skala sampel

$\mathrm{N}=$ Jumlah Keseluruhan Populasi

$\mathrm{e}=$ Persentase dispensasi penyimpangan

$x=\frac{26892}{1+26892 \times 0,05^{2}}$

$x=\frac{26892}{1+26892 \times 0,0025}$

$x=\frac{26892}{1+67,23}$

$x=\frac{26892}{67,2325}$

\section{Hipotesis}

Untuk mengetahui terdapat atau tidaknya hubungan maka terlebih dahulu membuat dugaan sementara atas jawaban dalam penelitian ini.

$\mathrm{H}_{0}$ : Tidak terdapat hubungan antara

Kemampuan 
Pemahaman Kosa Kata (X1) terhadap Strategi Belajar (Y)

$\mathrm{Ha}$ : Terdapat hubungan antara Kemampuan Pemahaman (X1) terhadap Strategi Belajar (Y)

$\mathrm{H}_{0}$ : Tidak terdapat hubungan diantara Pronunciation (Pengucapan/ pelafalan) (X2) terhadap Strategi Belajar (Y)
Ha :Terdapat hubungan diantara Pronunciation (Pengucapan/ pelafalan) (X2) terhadap Strategi Belajar (Y)

\begin{tabular}{|c|c|c|}
\hline Jenis Variabel & Ukuran & Parameter \\
\hline \multirow{8}{*}{$\begin{array}{c}\text { Variabel } \\
\text { Independen } \\
\text { Strategi Belajar } \\
\text { (Prastowo, 2015) }\end{array}$} & \multirow{3}{*}{ Sikap (Afektif) } & - Kepekaan terhadap keadaan sekitar \\
\hline & & $\begin{array}{l}\text { - Kemampuan diri seseorang untuk } \\
\text { melibatkan diri/berpartisipasi }\end{array}$ \\
\hline & & - Integritas dan kejujuran \\
\hline & \multirow{3}{*}{$\begin{array}{l}\text { Pengetahuan } \\
\text { (Kognitif) }\end{array}$} & $\begin{array}{l}\text { - Kemampuan untuk menilai baik } \\
\text { atau tidak sikap atau perilaku }\end{array}$ \\
\hline & & $\begin{array}{l}\text { - Kemampuan Intektual dalam } \\
\text { berpikir }\end{array}$ \\
\hline & & $\begin{array}{l}\text { - Kemampuan dalam memecahkan } \\
\text { suatu masalah }\end{array}$ \\
\hline & \multirow{2}{*}{$\begin{array}{l}\text { Keterampilan } \\
\text { (Psikomotorik) }\end{array}$} & $\begin{array}{l}\text { - Kemampuan untuk mengetahui } \\
\text { /pengetahuan terhadap suatu ilmu }\end{array}$ \\
\hline & & $\begin{array}{l}\text { - Kemampuan siswa dalam bertanya } \\
\text { terhadap apa yang telah diajarkan }\end{array}$ \\
\hline
\end{tabular}

Tabel 1. Jenis Variabel , Ukuran dan Parameter

\begin{tabular}{|c|c|c|}
\hline Jenis Variabel & Ukuran & Parameter \\
\hline \multirow{3}{*}{$\begin{array}{c}\text { Variabel } \\
\text { Independen } \\
\text { Kemampuan } \\
\text { Pemahaman } \\
\text { (Laba, Nengah I } \\
\text { \& Rimayanthi, } \\
\text { 2018) }\end{array}$} & \multirow{3}{*}{$\begin{array}{l}\text { Mampu memahami } \\
\text { berbagai macam } \\
\text { fungsi bahasa dan } \\
\text { penekanannya }\end{array}$} & $\begin{array}{l}\text { - Dapat menjawab dengan benar } \\
\text { tes/pertanyaan }\end{array}$ \\
\hline & & - Mengerti fungsi penekanan bahasa \\
\hline & & $\begin{array}{l}\text { - Memahami fungsi bahasa yang } \\
\text { terdapat dalam sebuah kalimat }\end{array}$ \\
\hline \multirow{3}{*}{$\begin{array}{c}\text { Variabel } \\
\text { Dependen } \\
\text { Pronunciation } \\
\text { (Pengucapan/pela } \\
\text { falan) (Penulis, } \\
\text { 2006) }\end{array}$} & \multirow[b]{3}{*}{ Mendengar } & - Mendengar kata kata dengan benar \\
\hline & & - Melakukan intruksi yang didengar \\
\hline & & $\begin{array}{l}\text { Memiliki keingintahuan } \\
\text { buku, suart kabar dan media } \\
\text { pembelajaran/informasi lain }\end{array}$ \\
\hline
\end{tabular}




\section{HASIL DAN PEMBAHASAN}

\section{Uji Validitas Variabel X1, X2, dan Y}

Penelitian yang dilakukan oleh (Syahputra, 2017) menunjukkan bahwa untuk menentukan apakah data tersebut valid atau tidak valid maka dapat dilihat dari besar nilai signifikansi dan pearson correlation. Apabila besar nilai signifikansi lebih kecil dari 0,05 dapat disimpulkan bahwa instrumen penelitian valid. Selanjutnya menentukan validitas dengan pearson correlation. Andaikan besar nilai koefisien korelasi lebih besar dari 0,03 dapat dikatakan butir pertanyaan tersebut dikatakan valid. Perhitungan validitas yang terdiri dari variabel $\mathrm{X} 1, \mathrm{X} 2$ dan $\mathrm{Y} 1$ yang diteliti menujukkan hasilnya adalah valid karena nilai $r_{\text {hitung }}>r_{\text {tabel. }}$ Butir pertanyaan pertama sebesar $r=0,871$ yang dibandingkan dengan r-tabel sebesar 0,098, atau jika dituliskan dalam bentuk perhitungan matematika r-hitung $(0,871)>$ r-tabel 0,098. Dari ketiga variabel yang dihitung X1, X2 dan Y maka didapatkan semua butir dari masingmasingvariabel valid. Hal ini sesuai dengan pendapat (Widiyanto, 2014)

\section{Realibilitas}

Hasil penelitian (Syahputra, 2017) menunjukkan bahwa Hasil uji realibilitas disebut realibel asalkan memiliki batasan nilai (a) sebesar 0,70. Berdasarkan dari hasil perhitungan diketahui Cronbanch's Alpha dari ketiga variabel diatas 0,7, berdasarkan hal tersebut maka dapat ditarik kesimpulan bahwa antara variabel (X1), (X2) dan (Y) realibel.

Tabel 2. Data Hasil Uji Perhitungan Realibilitas

\begin{tabular}{|l|c|c|c|}
\hline \multicolumn{1}{|c|}{ Kategori Variabel } & $\begin{array}{c}\text { Nilai Cronbach } \\
\text { Alpha }\end{array}$ & $\begin{array}{c}\text { Standar } \\
\text { Batasan }\end{array}$ & $\begin{array}{c}\text { Kesimpulan } \\
\text { Realibilitas }\end{array}$ \\
\hline $\begin{array}{l}\text { Kemampuan Pemahaman } \\
\text { Kosa Kata (X1) }\end{array}$ & 0,911 & 0,7 & Realibel \\
\hline $\begin{array}{l}\text { Pronunciation } \\
\text { (Pengucapan/pelafalan) } \\
\text { (X2) }\end{array}$ & 0,907 & 0,7 & Realibel \\
\hline $\begin{array}{l}\text { Strategi Belajar Dengan } \\
\text { Metode Bimbel Online } \\
\text { (Y) }\end{array}$ & 0,913 & 0,7 & Realibel \\
\hline
\end{tabular}

\section{Uji Regresi Berganda}

Berdasarkan hasil perhitungan dari Tabel 4.6 Uji regresi maka diperoleh Nilai $R$, R Square $\left(R^{2}\right)$ dan Adjusted R Square. Hasil Nilai R menujukkan dalam variabel (X1) dan (X2) saling berpengaruh dengan variabel (Y) atau biasa disebut dengan istilah variabel saling korelasi berganda, Hal ini juga sesuai Nilai $\mathrm{R}$ Square $\left(\mathrm{R}^{2}\right)$ pada dasarnya menjelaskan sumbangan pengaruh. dengan pendapat dari (Wijaya, 2012) yang menjelaskan bahwa dalam regresi linier berganda, nilai $\mathrm{R}$ sebesar 0,955 menunjukkan korelasi berganda (Kemampuan Pemahaman Kosa Kata Bahasa Inggris dan Pronunciation

(Pengucapan/pelafalan)) dengan Strategi Belajar Dengan Metode Bimbel Online.

Seperti pendapat yang dijelaskan oleh Priyatno (2012:134) yang 
menjelaskan bahwa $\mathrm{R}$ Square $\left(\mathrm{R}^{2}\right)$ atau kuadrat $\mathrm{R}$ menunjukkan nilai Angka koefisien determinasi yang menunjukkan makna kontribusi dampak antara variabel (X1), (X2) terhadap (Y) dalam bentuk persen. Angka R2 sebesar 0,912 yang bermakna kontribusi variabel Kemampuan Pemahaman Kosa $\mathrm{Kata}(\mathrm{X} 1)$ dan Pronunciation (Pengucapan/pelafalan) terhadap Strategi Belajar (Y) sebesar $91,2 \%$, sedangkan sisa $8,8 \%$ dipengaruhi oleh variabel lain yang tidak dimasukkan dalam model
ini.Sementara itu nilai Adjusted $R$ Square merupakan nilai $\mathrm{R}$ Square yang sudah disinkron(Priyatno, 2012). Angka Adjusted $R$ Square sebesar 0,911 yang memperlihatkan bahwa dampak kontribusi antara Kemampuan Pemahaman Kosa Kata (X1) dan Pronunciation (Pengucapan/pelafalan) terhadap Strategi Belajar (Y).Apabila terdapat lebih dari dua variabel independen maka pengukuran sumbangsih antara variabel menggunakan Adjusted R Square.

Tabel 3. Perhitungan Hasil Uji Regresi

\section{Model Summary}

\begin{tabular}{lr|r|r|r|r} 
Model & $\mathrm{R}$ & RSquare & \multicolumn{1}{|c|}{$\begin{array}{c}\text { AdjustedR } \\
\text { Square }\end{array}$} & $\begin{array}{c}\text { Std.Errorof } \\
\text { theEstimate }\end{array}$ & Durbin-Watson \\
\hline 1 &, $955^{\mathrm{a}}$ &, 912 &, 911 & 1,180 & 2,130 \\
\hline
\end{tabular}

a. Predictors: (Constant), Pronunciation (Pengucapan/pelafalan) (X2), Kemampuan Pemahaman Kosa Kata Bahasa Inggris (X1)

b. Dependent Variable: Strategi Belajar Dengan Metode Bimbel Online (Y)

\section{Uji T-Test}

Tabel 4. Perhitungan T-Test

\section{Coefficients $^{\mathrm{a}}$}

\begin{tabular}{|c|c|c|c|c|c|c|}
\hline \multirow{2}{*}{\multicolumn{2}{|c|}{ Model }} & \multicolumn{2}{|c|}{$\begin{array}{l}\text { Unstandardized } \\
\text { Coefficients }\end{array}$} & \multirow{2}{*}{$\begin{array}{c}\text { Standardized } \\
\text { Coefficients } \\
\text { Beta } \\
\end{array}$} & \multirow[b]{2}{*}{$\mathrm{t}$} & \multirow[b]{2}{*}{ Sig. } \\
\hline & & B & Std.Error & & & \\
\hline \multirow[t]{3}{*}{1} & (Constant) & 1,040 &, 507 & & 2,052 &, 041 \\
\hline & $\begin{array}{l}\text { Kemampuan } \\
\text { Pemahaman Kosa } \\
\text { Kata Bahasa Inggris } \\
\text { (X1) }\end{array}$ & ,221 &, 053 & ,221 & 4,143 & ,000 \\
\hline & $\begin{array}{l}\text { Pronunciation } \\
\text { (Pengucapan/pelafala } \\
\text { n) (X2) }\end{array}$ & ,748 &, 054 & ,741 & 13,909 &, 000 \\
\hline
\end{tabular}

a. Dependent Variable: Strategi Belajar Dengan Metode Bimbel Online (Y)

Kemampuan Pemahaman Kosa Kata Bahasa Inggris (X1)
Hipotesis :

$\mathbf{H}_{\mathbf{0}}=$ Kemampuan Pemahaman tidak berpengaruh Terhadap 
Strategi Belajar Dengan Metode Bimbel Online (Y)

$\mathbf{H}_{\mathbf{a}}$ =Kemampuan Pemahaman berpengaruh Terhadap Strategi Belajar Dengan Metode Bimbel Online (Y)

Proses Pengambilan Keputusan : Membandingkan antara $t_{\text {hitung }}$ dengan $t_{\text {tabel }}$

Jika $-\mathbf{t}_{\text {tabel }}<t$ hitung $<\mathbf{t}_{\text {tabel }}=\mathbf{H}_{0}$ diterima

Jika $-\mathbf{t}_{\text {hitung }}<-t_{\text {tabel }}<$ atau $t_{\text {hitung }}$ $>\mathbf{t}_{\text {tabel }}=\mathrm{H}_{0}$ ditolak

Untuk melihat hasil Uji t maka dapat dilakukan dengan melihat uji dua sisi ( 2 tailed) $0,05 / 2=0,025$. Hasil thitung didapatkan 4,143. Cara mencari t kritis dapat dicari pada tabel statistik pada signifikansi (uji 2 sisi) $\quad 400-2-1=397 \quad$ sehingga didapatkan nilai t kritis 1,966.

Dalam hasil pengujian didapatkan nilai $\mathrm{t}$ hitung sebesar 4,143 . Sementara untuk nilai $t$ tabel 1,966 , atau dengan nama lain jadi hipotesis nol ditolak. Berdasarkan hasil uji menunjukkan Kemampuan Penguasaan memiliki pengaruh dengan Strategi Belajar.

\section{Melihat nilai probabilitas}

Apabila probabilitas $>0,05$ maka $\mathrm{H}_{0}$ diterima

Apabila probabilitas $<0,05$ maka $\mathrm{H}_{0}$ ditolak

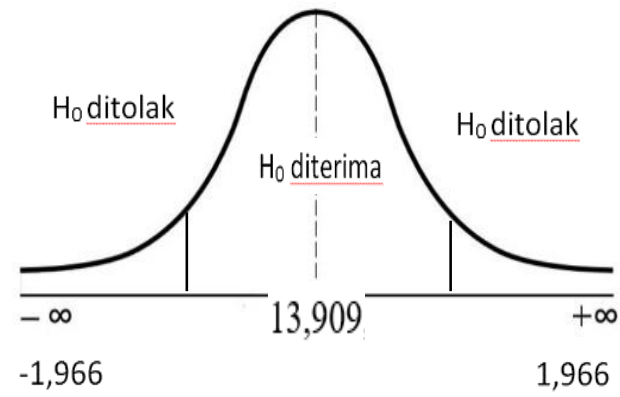

Nilai probabilitas sebesar 0,000 $<0,05$ maka hipotesis nol ditolak, dengan kata lain Kemampuan Penguasaan memiliki pengaruh dengan Strategi Belajar.

\section{Gambar 3. Distribusi Normal Pada} Kemampuan Penguasaan (X1)

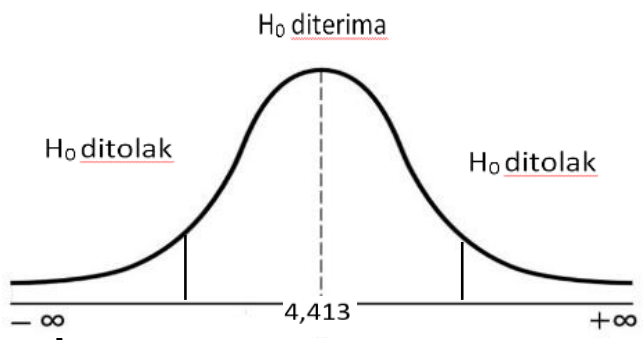

-1,966 Pronunciation (Penguc 1,966' pelafalan) (X2) tidakTerhadap Strategi Belajar Dengan Metode Bimbel Online (Y)

$\mathbf{H}_{\mathbf{a}}=$ Pronunciation (Pengucapan/ pelafalan) (X2)berpengaruh Terhadap Strategi Belajar Dengan Metode Bimbel Online (Y)

Mengambil keputusan berdasarkan nilai probabilitas $(\mathrm{t})$

Apabila probabilitas $>0,05, \mathrm{H}_{0}$ diterima maka $\mathrm{H}_{\mathrm{a}}$ ditolak

Apabila probabilitas $<0,05, \quad \mathrm{H}_{0}$ ditolak maka $\mathrm{H}_{\mathrm{a}}$ diterima

Jika $\mathbf{t}$ hitung $<\mathrm{t}$ tabel $=\mathbf{H}_{0}$ diterima

Jika $t_{\text {hitung }}>t_{\text {tabel }}=\mathbf{H}_{0}$ ditolak

Jika angka $t$ hitung sebesar 13,909, maka angka ini akan dibandingkan dengan t tabel. Angka t tabel didapatkan sebesar 1,966, maka $t$ hitung lebih besar daripada $t$ tabel.

Pengambilan keputusan berdasarkan angka probabilitas maka didapatkan nilai probabilitas sebesar 0,000 jadi disimpulkan $\mathrm{H}_{0}$ diterima maka $\mathrm{H}_{\mathrm{a}}$ ditolak

Gambar4. Distribusi Normal Pada Penguasaan Kosa kata (X2) 


\section{Uji F}

Pada dasarnya Uji F merupakan regresi secara serentak seperti menjelaskan pengaruh variabel independen secara serentak, seperti menjelaskan dampak variabel bebas secara serentak kepada variabel tidak bebas, memiliki pengaruh signifikan atau tidak(Priyatno, 2013). Secara perhitungan didapatkan data Nilai $F$ tabel sebesar 3,018 dan $\mathrm{F}$ hitung 2047,943 , maka dapat disimpulkan 2047,943 >3,018 . X1 (Kemampuan Pemahaman) dan X2 (Pronunciation (Pengucapan/ pelafalan)) secara bersama berpengaruh terhadap variabel terikat Y (Strategi Belajar Dengan Metode Bimbel Online, seperti yang tertera di tabel 4.3 seperti ini:

Tabel 5. Hasil Olah Data Uji F

\begin{tabular}{|c|c|c|c|c|c|c|}
\hline \multicolumn{7}{|c|}{ ANOVA $^{a}$} \\
\hline \multicolumn{2}{|c|}{ Model } & Sum of Squares & df & MeanSquare & $\mathrm{F}$ & Sig. \\
\hline 1 & Regression & 5701,968 & 2 & 2850,984 & 2047,943 &, $000^{\mathrm{b}}$ \\
\hline & Residual & 552,672 & 397 & 1,392 & & \\
\hline & Total & 6254,640 & 399 & & & \\
\hline
\end{tabular}

a. Dependent Variable: Strategi Belajar Dengan Metode Bimbel Online (Y)

b. Predictors: (Constant), Pronunciation (Pengucapan/pelafalan) (X2), Kemampuan

Pemahaman Kosa Kata Bahasa Inggris (X1)

\section{SIMPULAN}

Berdasarkan dari hasil peneltian yang telah penulis lakukan dengan menyebarkan kuesioner yang berlokasi di tempat umum di Jakarta Utara menunjukkan bahwa Kemampuan Pemahaman berpengaruh secara signifikan dan positif terhadap Strategi Belajar Dengan Metode Bimbel Online (Y). Sementara itu untuk Pronunciation (Pengucapan/pelafalan)

(X2)berpengaruh secara signifikan dan positif terhadap Strategi Belajar Dengan Metode Bimbel Online (Y). Hal ini juga serupa dengan penelitian yang dilakukan oleh (Sofiyanti, 2014) menunjukkan terdapat pengaruh yang bernilai positif antara penggunaan media online English Pronounciation dengan peningkatan kemampuan pengucapan bahasa Inggris siswa.

Semoga dari hasil penelitian ini dapat menambah pengetahuan khususnya remaja dalam menggunakan istilah asing, sehingga diharapkan mereka tidak salah dalam penggunaan istilah asing ini untuk percakapan sehari-hari. Hal ini sangat penting karena agar tidak membingungkan orang lain dan khususnya orang asing ketika remaja tersebut menggunakan istilah asing dalam percakapan sehari-hari.

\section{DAFTAR PUSTAKA}

Aliwanto. (2017). Analisis Aktivitas Belajar Siswa. Jurnal Konseling GUSJIGANG, Vol. 3 No., 64-71, Print ISSN 2460-1187 Online ISSN 2503281X. https://doi.org/DOI: http://dx.doi.org/10.24176/jkg.v3i1.1112

50| Jurnal Kredo Vol. 2 No. 1 Oktober 2018 
Budiarto, eko. (2004). Metodologi Penelitian Kedokteran Sebuah Pengantar. Jakarta: EGC.

Bungin, B. (2017). Metodologi Penelitian Kunatitatif. Jakarta: Kencana.

Chatib, M. (2011). Gurunya Manusia. Bandung: Kaifa.

Cook, V. (2016). Second Language Learning and Language Teaching. New York: Fifth Edition.

Elsjelyn, Evelyn, R. (2014). English Made Easy. Jakarta: Kesaint Blanc.

Enterprise, J. (2010). 30 Bisnis Berbasis Ide Untuk Siapa Pun. Jakarta: PT. Elex Media Komputindo.

Gideon, S. (2018). Peran Media Bimbingan Belajar Online "Ruangguru" Dalam Pembelajaran Ipa Bagi Siswa SMP dan SMA Masa Kini: Sebuah Pengantar. Jurnal JDP, 11, 167-182.

Gusrayani, D. (2014). Teaching English to Young Laerners. Bandung: UPI Press.

Hakim, T. (2005). Belajar Secara Efektif. Jakarta: Pustaka Pembangunan Swadaya Nusantara.

Hakim, T. (2008). Cara Termudah Membuat Kalimat Percakapan Bahasa Inggris (English Conversation). Jakarta: PT Kawan Pustaka.

Herlina. (2015). Meningkatkan Pemahaman Kosakata Bahasa Inggris Melalui Metode Permainan Bingo. Jurnal Ilmiah VISI PPTK PAUDNI, Vol. 10, N, 114-121.

Hornby. (2003). Oxford Advanced Learner's Dictionary. Oxford: Oxford University.

Jaya, M. S. (2017). Strategi Pembelajaran Pelafalan Bahasa Inggris Materi Front Office Melalui Kartu Tematik Bagi Mahasiswa Manajemen Perhotelan. Jurnal Linguistika, Vol. 24. N, 72-84 ISSN: 0854-9613.

Keraf, G. (2007). Diksi dan Gaya Bahasa. Jakarta: PT. Gramedia Pustaka Utama.

Laba, Nengah I \& Rimayanthi, M. N. (2018). Buku Ajar Bahasa Indonesia. Yogyakarta: Deepublish.

M.Zaim. (2013). Asesmen Otentik: Implementasi Dan Permasalahannya Dalam Pembelajaran Bahasa Inggris Di Sekolah Menengah. In Proceeding of the International Seminar on Languages and Art (pp. 29-61. ISBN: 978-60217017-2-0).

Mariyanto, T. (2017). Mitos Kesuksesan Dalam Iklan Bimbingan Belajar Kumon. The Journal of Society \& Media, Vol. 1(1), 43-66. Retrieved from https://journal.unesa.ac.id/index.php/jsm/index

Penulis, T. (2006). Model Silabus Sekolah Dasar Kelas 4. Jakarta: Grasindo.

Permadi, I. (2014). Hak Atas Tanah Bagi Warga Negara Asing. Malang. Malang: Gunung Samudra.

Prasetya et al. (2013). Bimbingan Belajar Efektif Untuk Meningkatkan Kebiasaan Belajarpada Siswa Kelas VII. Jurnal Prediksi, Kajian Ilmiah Psikologi, Vol.

ANALISIS STRATEGI BELAJAR DENGAN METODE BIMBEL ONLINE / 51 
2, hal. 1-4.

Prastowo, A. (2015). Menyusun Rencana Pelaksanaan Pembelajaran (RPP) Tematik Terpadu. Jakarta: Kencana.

Priyatno, D. (2012). Cara Kilat Analisis Data Dengan SPSS 20. Yogyakarta: ANDI.

Priyatno, D. (2013). Analisis Korelasi, Regresi, dan Multivariate dengan SPSS. Yogyakarta: Gava Media.

Sofiyanti, Y. (2014). Upaya Meningkatkan Kemampuan Pengucapan Bahasa Inggris Dengan Media Pembelajaran Online English Pronounciation. Jurnal Wawasan Ilmiah Manajemen Dan Teknik Informatika, Volume 6, 16-29 ISSN : 1978-8444.

Susanto, A. (2018). Bimbingan dan Konseling di Sekolah Konsep, Teori, dan Aplikasinya. Jakarta: Prenada Media Group.

Syahputra, D. (2017). Pengaruh Kemandirian Belajar dan Bimbingan Belajar Terhadap Kemampuan Memahami Jurnal Penyesuaian Pada Siswa Sma Melati Perbaungan. At-Tawassuth Jurnal Ekonomi Syariah, Vol. II, N, 368 388.

Warsiman. (2016). Membumikan Pembelajaran Satra Yang Humanis. Malang: Universitas Brawijaya Press.

Widiyanto, M. A. (2014). Statistika Untuk Penelitian Bidang Teologi, Pendidkan, Agama Kristen, \& Pelayanan Gereja. Bandung: Kalam Hidup.

Wijaya, T. (2012). Praktis dan Simpel Cepat Menguasai SPSS 20. Yogyakarta: Cahaya Atma Pustaka. 